\title{
Stabilization of wines with polymers and new bio-based carbon materials.
}

\author{
Veronica Andreeva*, Vera Kashparova, Daria Chernysheva, Denis Tokarev, and Yash \\ Kataria \\ Platov South-Russian State Polytechnic University (NPI), Prosveshcheniya str., 132, Novocherkassk, \\ 346428, Russia
}

\begin{abstract}
Wine is a complex product which changes its properties at every production stage, however due to the different processes which take place in the production stage can result into the formation of unwanted turbidity, deposition or can lead to distortion of taste. Despite the advances in improving wine stabilization processes, the search for new materials continues. The present work focuses on clarification of wines on the basis of new polymers and carbon materials obtained from bio-renewable raw materials and byproducts from the production of 2,5-hydroxymethylfurfural (5-HMF).
\end{abstract}

\section{Introduction}

An important quality for all types of wines - red, pink and white - is the preservation of their unique qualities, taste, color and aroma. Oxidative processes inherent in such complex systems as wine, lead to deterioration in taste, loss of brightness and formation of oxidation tones, which in turn reduces the quality of wine. To solve this problem, various technological methods are used to reduce oxidation at all the technological stages, by selecting suitable temperature regimes, as well as selecting various clarifiers and stabilizers. The wine clarification process involves removing suspended and colloidal particles that create turbidity, as well as removing unstable proteins or other macromolecules that can later denature or aggregate, resulting in a cloudy appearance of the wine after bottling. The purpose of stabilization is to ensure the clarity of the wine during aging and storage. Stabilization is carried out by removal (adsorption) of polyphenolic, protein and crystalline compounds with gluing agents, as well as filtration using membranes [1-4]. Traditionally, these are bentonite of various modifications, fish glue, albumin, chitosan (and others) and polymer compounds - PVP, PAA, and POE in combinations required for a specific stabilization method [5].

In addition, the removal of metal ions (primarily $\mathrm{Fe}$ (II), $\mathrm{Cu}$ (II)), $\mathrm{Ni}$ (II), as well as sulfur compounds that can get into the wine material as a result of processing grapes from various diseases is of great importance in the stabilization and safety of wines, from soil and technological operations [6-9].

\footnotetext{
* Corresponding author: veronica.andreeva@gmail.com
} 
By developing and studying new polymeric materials and adsorbents, primarily based on bio-renewable plant raw materials, we can get an idea about the possibility of their targeted use to obtain high-quality wines.

The aim of the current research was to study the brightening and stabilizing properties of new copolymers based on 2,5-diallylfuranate and acrylic (AAc/DAF) or methacrylic acids (MAAc/DAF) which were obtained from bio-renewable raw materials.

\section{Materials and methods}

The efficiency of removing metal cations and polyphenolic compounds was evaluated using two model systems from Rkatsiteli and Cabernet-Sauvignon wines. The mixture of dry white wine of the Rkatsiteli variety, dry red wine of the Cabernet - Sauvignon variety was selected with the addition of tannin (mass concentration 80 and $1000 \mathrm{mg} / \mathrm{dm} 3$, respectively) and metal salts $\mathrm{Cu}$ (II) and $\mathrm{Ni}$ (II) (mass concentration $20 \mathrm{mg} / \mathrm{dm} 3$, respectively). The amount of introduced substances was determined based on the recommended safe values and analysis of literature data $[10,11]$.

Physicochemical indicators of wines were determined according to standardized methods operating in the territory of the Russian Federation; dry wines of the varieties Rkatsiteli, Cabernet - Sauvignon, obtained according to the schemes for the preparation of white and red dry wines. The investigated model wine samples were treated with various sorbents to establish optimal dosages and achieve stability.

As sorbents, synthesized polymeric materials from bio-renewable raw materials [12] were used together with activated carbons obtained from wastes of the agricultural industry and the production of 5-HMF [13]. The total exchange capacity for binary copolymers DAF, depending on the amount of the cross linking agent (2.5-10 mol\%), was $8.3-9.5 \mathrm{meq} / \mathrm{g}$, and the sorption capacity for heavy metal ions was $365 \mathrm{mg} / \mathrm{g}$ and $290 \mathrm{mg} / \mathrm{g}$ (dry adsorbent) respectively for $\mathrm{Ni}$ (II) and $\mathrm{Cu}$ (II). The specific surface area of activated carbons according to the BET method was $600-860 \mathrm{~m}^{2} / \mathrm{g}$ (coal obtained by carbonization of humines - up to $860 \mathrm{~m}^{2} / \mathrm{g}$; coal obtained by carbonization of beet pulp - $600 \mathrm{~m}^{2} / \mathrm{g}$ ). For comparison, bentonite (in the form of a 10\% suspension) was used. The studied dosages of sorbents were $2.0 \mathrm{~g} / \mathrm{dm}^{3}$.

The brightening ability of the studied polymers and CMs was determined by the colorimetric method. The content of phenolic substances was determined according to the method recommended by the International Organization of Wine and Viticulture (OIV).

The efficiency of removing heavy metal ions was determined by analyzing the difference in the concentration of these metals in wine before and after adsorption. The concentration of heavy metals was determined by the method described in [12].

All determinations and tests were carried out in triplicate (repeated three times).

\section{Results and discussion}

Bentonite is used in the wine industry to remove proteins that are a potential source of cloudiness in wine. Through interaction with positively charged hydrocolloids and adsorption, bentonite interacts not only with proteins, but also with other molecules. Bentonite is used in combination with other adsorbents such as activated carbons or various polymers (polyvinylpolypyrrolidone, polyacrylamide, etc.). As a control, we used Plaxbenton bentonite (Table).

Copper at a concentration of $5 \mathrm{mg} / \mathrm{dm}^{3}$ negatively affects the taste of wine. Ferrous iron does not cause turbidity, but, being oxidized by atmospheric oxygen to Fe (III), combines with phenolic substances to form chelate compounds. As a result, sparingly soluble metallotanide-protein complexes are obtained; causing clouding of wines and the appearance 
of sediment. The complex bound iron is not adsorbed by bentonites. In this case, mixtures of bentonite with other adsorbents or complexing agents are used [14, 15].

It is on the binding of metals that the action of the AAc/DAF and MAAc/DAF copolymers is directed, which also show activity against pathogenic micro flora [12]. After the treatment of wine samples with an initial content of $\mathrm{Ni}$ (II) and $\mathrm{Cu}$ (II) of $20 \mathrm{mg} / \mathrm{dm}^{3}$ each, with the copolymers the content of heavy metal ions decreased almost 10 times and was less than $3 \mathrm{mg} / \mathrm{dm}^{3}$.

Activated carbons with a high specific surface area and high porosity are widely used as sorbents. Joint stepwise introduction of sorbents (bentonite + CM2, polymers + CM2) showed the maximum removal of tannins, with the formation of clumping, easily separable sediments.

The carbon materials considered in this study were obtained from humic or beet pulp using one-step and two-step processes involving chemical and physical activation methods (denoted as Chem and Phys, respectively). The preparation conditions for each carbon material (temperature and amount of modifier) are reflected in the names of the samples. For example, Chem - 900 - 4 refers to a carbon material obtained by chemical activation of humins at $900{ }^{\circ} \mathrm{C}$ and a mass ratio of $\mathrm{KOH} /$ humins of $4: 1$; Chem * $-900-1.5$ refers to a carbon material obtained by chemical activation of beet pulp at $900^{\circ} \mathrm{C}$ and a mass ratio of $\mathrm{H}_{3} \mathrm{PO}_{4} /$ pulp of 1.5:1. A detailed description of the preparation methods and characteristics of the obtained materials are given in [13]. Samples of CM from beet pulp were obtained in a similar way. For the tests, materials with a maximum specific surface area of $600-860 \mathrm{~m}^{2} / \mathrm{g}$ were selected; the results of processing model wine solutions are presented in Table.

Table. Chromatic characteristics of model wine solutions, where CA- activated carbon, CM1- beet pulp carbon material, CM2 - carbon material from production waste 2,5 -HMF

\begin{tabular}{|c|c|c|c|c|c|c|c|}
\hline \multirow[t]{3}{*}{ № } & \multirow{3}{*}{$\begin{array}{l}\text { Concentration of } \\
\text { sorbents, by } 2,0 \mathrm{~g} / \mathrm{dm}^{3}\end{array}$} & \multirow{2}{*}{\multicolumn{3}{|c|}{$\begin{array}{c}\text { Model white wine solution } \\
\text { Optical characteristics }\end{array}$}} & \multirow{2}{*}{\multicolumn{3}{|c|}{$\begin{array}{c}\text { Model red wine solution } \\
\text { Optical characteristics } \\
\end{array}$}} \\
\hline & & & & & & & \\
\hline & & $\begin{array}{c}\text { Bright- } \\
\text { ness, } \\
\mathrm{Y}, \% \\
\end{array}$ & $\begin{array}{c}\text { Chroma- } \\
\text { ticity, } \lambda, \\
\text { nm }\end{array}$ & $\begin{array}{l}\text { Clarity, } \\
\text { P, \% }\end{array}$ & $\begin{array}{c}\text { Bright- } \\
\text { ness, } \\
\text { Y, \% }\end{array}$ & $\begin{array}{c}\text { Chroma- } \\
\text { ticity, } \lambda, \\
\text { nm }\end{array}$ & $\begin{array}{l}\text { Clarity, } \\
\text { P, \% }\end{array}$ \\
\hline 1 & $\begin{array}{l}\text { Control (without } \\
\text { additives) }\end{array}$ & 88,40 & 589,0 & 8,0 & 29.21 & 540,0 & 47.0 \\
\hline 2 & Bentonite & 87,10 & 589,0 & 8,4 & 24.65 & 538,6 & 46,5 \\
\hline 3 & CA (control) & 86,90 & 580,4 & 8,1 & 26.72 & 539,4 & 46,9 \\
\hline 4 & CM 1* & 85,88 & 589,1 & 7,5 & 28.11 & 539,7 & 45,2 \\
\hline 5 & CM 2** & 82,08 & 588,2 & 8,7 & 25.19 & 538,5 & 46,9 \\
\hline 6 & Bentonite + YA & 83,20 & 586,1 & 8,5 & 23,01 & 539,0 & 47,2 \\
\hline 7 & Bentonite + CM 1* & 81,15 & 584,8 & 8,9 & 22,48 & 539,0 & 47,9 \\
\hline 8 & Bentonite + CM 2** & 81,00 & 581,1 & 9,9 & 21.11 & 538,2 & 50,2 \\
\hline 9 & Polymer AAc/DAF & 81,06 & 585,4 & 5,0 & 25.14 & 539,1 & 49,1 \\
\hline 10 & $\begin{array}{l}\text { Polymer AAc/DAF } \\
+ \text { YA }\end{array}$ & 76,70 & 584,2 & 5,5 & 24,43 & 539,1 & 49,4 \\
\hline 11 & $\begin{array}{l}\text { Polymer AAc/DAF + } \\
\text { CM } 1\end{array}$ & 76,00 & 574,0 & 8,1 & 23,15 & 538,1 & 51,8 \\
\hline 12 & $\begin{array}{l}\text { Polymer AAc/DAF + } \\
\text { CM } 2\end{array}$ & 71,30 & 570,1 & 10,0 & 22,15 & 537,0 & 52,4 \\
\hline
\end{tabular}

* - beet pulp carbon material Chem* $-900-1,5$;

** - Carbonaceous material from humins Chem-900-4;

From the table it can be seen that upon the treatment of the sample solutions with the studied sorbents leads to an increase in brightness and purity, and the combined pasting with the polymers based on bio-renewable raw materials with new carbon materials makes it possible to achieve brightness and brilliance In addition, the removal of metal ions that are naturally present in wine (such as iron, nickel and copper) and catalyze the oxidation of 
volatile aromatics, which cause darkening and cloudiness of the wine, contributes to more stable wines.

\section{Conclusion}

The use of AAc/DAF and MAAc/DAF copolymers for the treatment of model wines promotes the selective removal of heavy metals and partial removal of phenolic compounds, which prevents browning and precipitation.

Currently, interest in the problem of obtaining wines free from heavy metals and other pollutants using polymeric materials remains relevant. Therefore, work is underway to create new polymer materials, which are medium- or weakly cross-linked polymer networks with hydrophilic properties, can be used as traditional cation exchangers, adsorbents, depending on the degree of cross-linking and the ability to swell and absorb metal ions. In addition, carbon materials obtained from humic waste from 5-HMF production showed good results in stabilizing model wines, which are not inferior to control carbon materials. At the same time, the processing of agricultural waste or 5-HMF synthesis products will make it possible to switch to bio-renewable raw materials and will help reduce the carbon footprint. The obtained materials showed good results on the sample solutions, which confirmed the possibility of their use for the stabilization of wines. To develop practical recommendations for their use in winemaking, it is necessary to conduct a more thorough comprehensive research in wines.

Acknowledgments. The work was done using equipment of Center for Shared Equipment «Nanotechnology» of Platov South-Russian State Polytechnic University (NPI) and financially supported by the Russian Science Foundation (No. 21-13-00177).

\section{References}

1. J. Moreno, R. Peinado, Enological Chemistry (Academic Press, 2012) https://doi.org/10.1016/C2011-0-69661-9

2. A. Mierczynska-Vasilev, P. A. Smith, Aust. J. Grape Wine Res., 21, 615-626 (2015) https://doi.org/10.1111/ajgw.12198

3. A. Bosso, S. Motta, L. Panero, S. Lucini, M. Guaita, J. Food Sci., 85(8), 2406-2415 (2020) http://doi.irg/10.1111/1750-3841.15342

4. R. Chagas, S. Monteiro, R. Boavida Ferreira, Am. J. Enol. Vitic., 63, 574-578 (2012) https://doi.org/10.5344/ajev.2012.12016

5. M.P. Martínez-Pérez, A.B. Bautista-Ortin, V. Durant, E. Gómez-Plaza, Foods, 9(9), 1275 (2020). https://doi.org/10.3390/foods9091275

6. G. D. Dumitriu, C. Teodosiu, I. Morosanu, O. Jitar, V.V. Cotea, BIO Web Conf., 15, 02024 (2019) https://doi.org/10.1051/bioconf/20191502024

7. B. Tariba, Biol. Trace Elem. Res., 144, 143-56 (2011) https://doi.org/10.1007/s12011011-9052-7

8. J. R. Lamichhane, E. Osdaghi, F. Behlau, J. Köhl, J. B. Jones, J.N. Aubertot, Agron. Sustain. Dev., 38(3), 28 (2018) https://doi.org/10.1007/s13593-018-0503-9

9. M.Z. Viviers, M.E. Smith, E. Wilkes, P. Smith, J. Agric. Food Chem., 61, 50, 1238512396 (2013) https://doi.org/10.1021/jf403422x

10. M.Z. Bekker, M.P. Day, P.A. Smith, Molecules, 24(8), 1523 (2019) https://doi.org/10.3390/molecules24081523

11. E.P. Pérez-Álvarez, R. Garcia, P. Barrulas, C. Dias, M.J. Cabrita, T. Garde-Cerdán, Food Chem., 270, 273-280 (2019) https://doi.org/10.1016/j.foodchem.2018.07.087. 
12. V.A. Klushin, V.P. Kashparova, A.A. Chizhikova, V.E. Andreeva, D.V. Chernysheva, A.A. Ulyankina, O.Yu. Kutsevalova, N.V. Smirnova, O.A. Kravchenko, V.P. Ananikov, Chem. Eur. J., 27(10), 3382-3396 (2021) https://doi.org/10.1002/chem.202003643

13. D.V. Chernysheva, Y.A. Chus, V.A. Klushin, T.A. Lastovina, L.S. Pudova, N.V. Smirnova, O.A. Kravchenko, V.M. Chernyshev, V.P. Ananikov, ChemSusChem, 11(20), 3599-3608 (2018) https://doi.org/10.1002/cssc.201801757

14. R.B. Boulton, V.L. Singleton, L.F. Bisson, R.E. Kunkee, Principles and practices of winemaking, 604 (Springer Science \& Business Media, 2013) https://doi.org/10.1007/978-1-4757-6255-6

15. M. Lambri, R. Dordoni, M. Giribaldi, M. R. Violetta, M. G. Giuffrida, LWT - Food Sci. Technol., 46, 2 460-467 (2012) https://doi.org/10.1016/j.lwt.2011.11.022 